\title{
Pseudomonas aeruginosa antibodies in blood spots from patients with cystic fibrosis
}

\author{
V THANASEKARAAN, ${ }^{*}$ M S WISEMAN, ${ }^{*}$ R J RAYNER, $\dagger$ E J HILLER, $\dagger$ AND D J SHALE* \\ ${ }^{*}$ Respiratory Medicine Unit and †Department of Paediatrics, University of Nottingham, City Hospital
}

SUMmary The formation of antibodies to Pseudomonas aeruginosa may be the earliest indicator of pulmonary infection in patients with cystic fibrosis. To enable easy sampling in babies and young children an enzyme linked immunosorbent assay (ELISA) based on a blood spot sample taken on to blotting paper was developed. A sample of approximately $20 \mu$ l of blood was required. A high correlation and level of absolute agreement was shown between paired finger prick and venepuncture blood spots, and between blood spot, serum spot, and serum samples. Healthy controls and non-infected patients with cystic fibrosis had low titres of antibody compared with patients with intermittent and chronic infection. The latter groups had significantly greater antibody titres than normal controls. This assay permits serial measurement of antibodies to $P$ aeruginosa in patients of all ages with cystic fibrosis and may provide a means of assessing the value of such measurements in the detection and management of early infection.

Chronic lung infection with Pseudomonas aeruginosa is the main cause of morbidity and mortality in patients with cystic fibrosis. ${ }^{1}$ There may be a period of harmless colonisation of the respiratory tract before infection becomes chronic, after which the organism is never completely eradicated from the lungs. Lung injury caused by chronic infection is probably mediated by the formation of immune complexes between $P$ aeruginosa derived antigens and host immunoglobulins. ${ }^{2}$

Chronic $P$ aeruginosa infection may be diagnosed by the determination of specific IgG class antibodies in serum by counterimmunoelectrophoresis or enzyme linked immunosorbent assay (ELISA). ${ }^{4-6} \mathrm{~A}$ specific antibody response may be detected before there is regular isolation of the organism from sputum. ${ }^{56}$ This early host response may also indicate the presence of lung injury, ${ }^{2}$ but it is not clear how knowledge of an increased antibody titre should be used in the management of patients in the early stages of $P$ aeruginosa infection.

The acquisition of $P$ aeruginosa occurs at an early age and it is in children that the application of antibody measurements may have the greatest potential for diagnosis and early treatment to protect the lungs. Serial determination of serum antibodies in young children is, however, difficult in practice and may be unacceptable to patients and parents. To overcome this an ELISA for IgG antibody to $P$ aeruginosa carried out on blood spot specimens from finger prick samples was developed.

\section{Subjects and methods}

Paired blood spot and serum samples were obtained by venepuncture from patients attending adult and paediatric cystic fibrosis clinics. Blood spot samples were also collected by finger prick. Data from the latter collection method are specifically indicated in the text. Adult patients with bronchiectasis and $P$ aeruginosa infection also had samples taken. These studies were approved by the local ethics committee. Controls were drawn from healthy hospital workers and their families, and from children having blood taken for other reasons.

\section{PROCESSING OF SPECIMENS}

Serum was stored at $-70^{\circ} \mathrm{C}$ until assay. Blood spots were collected onto Guthrie cards and stored in sealed plastic envelopes at $-20^{\circ} \mathrm{C}$. To control for the effect of the blotting paper and blood cells, spots were also made with freshly separated serum and dealt with in the same manner as the blood spots. The centre of each serum or blood spot was punched out using a standard $6 \mathrm{~mm}$ diameter paper punch. Each disc contained approximately $10 \mu \mathrm{l}$ of whole blood or $8 \mu \mathrm{l}$ serum (the serum dispersed over a larger area on the Guthrie cards) and was handled 
with forceps. The discs were incubated in $300 \mu \mathrm{l}$ of phosphate buffered saline $(\mathrm{pH} \mathrm{7.4)}$ for one hour at $37^{\circ} \mathrm{C}$ to elute antibody. The discs were removed and the eluate diluted 1:20 with phosphate buffered saline before assay.

ELISA

A direct antibody capture ELISA was developed using soluble antigens prepared from $P$ aeruginosa serotypes $01-17 .{ }^{7}$ The protein concentration of this preparation was $22 \mathrm{~g} / \mathrm{l}$. Flat bottomed, 96 well, cobalt irradiated, microtitre plates (Immulon 2, Dynatec) were coated with antigen in phosphate buffered saline, $\mathrm{pH} 7 \cdot 4(100 \mu \mathrm{l} /$ well, $1 \cdot 1 \mu \mathrm{g}$ protein $)$ for one hour. Excess antigen was removed by inversion of the plate and two washes with phosphate buffered saline. Blocking was performed with freshly prepared $0.05 \%$ gelatin solution in phosphate buffered saline $(100 \mu \mathrm{l} /$ well $)$ for one hour. Plates were then washed four times with phosphate buffered saline $0.01 \%$ Tween 20 (BDH) buffer. The first wash was a rapid one and the subsequent three entailed a four minute soak before emptying. Diluted serum (1:2000 in phosphate buffered saline) or eluate $(50 \mu \mathrm{l} /$ well $)$ was added and incubated for one hour. Plates were then washed four times as before. Biotinylated goat antihuman IgG $(\gamma$ chain specific, Sigma Chemical Co) diluted 1:1000 with phosphate buffered saline was added $(50 \mu \mathrm{l} /$ well $)$ and incubated for 60 minutes. Plates were washed four times as before. Avidin peroxidase conjugate (ICN Immunobiological Ltd) diluted $1: 1000$ in borate saline buffer $\mathrm{pH} 8.6(50 \mu \mathrm{l} /$ well $)$ was added and incubated for one hour. Wells were washed as before with a borate saline, $0.01 \%$ Tween 20 buffer (pH 8.6). The peroxidase substrate mixture was freshly prepared $(1 \mathrm{mg} / \mathrm{ml} \mathrm{5-amino} \mathrm{salicylic} \mathrm{acid,} \mathrm{in}$ $0 \cdot 02 \mathrm{M}$ phosphate buffer $\mathrm{pH} 6 \cdot 8$, was pretreated with $1-5 \mathrm{mg}$ of activated charcoal $/ 100 \mathrm{ml}$ and filtered before use, when $1 \mathrm{ml} / 100 \mathrm{ml}$ of freshly prepared $1 \%(\mathrm{v} / \mathrm{v})$ hydrogen peroxide was added). This solution $(100 \mu \mathrm{l} / \mathrm{well})$ was allowed to act for 30 minutes before $50 \mu \mathrm{l}$ of $3 \mathrm{M}$ sodium hydroxide was added to stop the reaction. Absorbance was read within five minutes of stopping the reaction in an automatic microtitre plate recorder (Kontron Ltd) at a wavelength of $455.5 \mathrm{~nm}$. Assays were performed at room temperature with continuous gentle mixing.

\section{STANDARDISATION OF ELISA DATA AND STATISTICAL} METHODS

A high titre serum from a patient with chronic pseudomonal infection, and a pool of normal low titre serum samples, were used as references. Nonspecific binding was reduced by using a high dilution and was controlled for by the inclusion of eight wells with no antigen on each plate. An ELISA index was derived as follows (OD, optical density):

$$
\frac{\text { Unknown OD-low control OD }}{\text { High control OD-low control OD }} \times 100
$$

Low control OD is the absorbance of the low titre serum in no antigen wells, high control OD is the absorbance of the high titre control serum, and unknown OD is the absorbance of the specimen being assayed ${ }^{8}$ Intra-assay and interassay variation were monitored with two whole blood spot samples assayed in eight replicates/assay.

Normally distributed data were expressed as mean and standard deviation or coefficient of variation (standard deviation/mean). Significance of differences were assessed by a Student's $t$ test. The relationships between sampling methods were compared by linear regression and a method of agreement. ${ }^{9}$ Non-normally distributed data were expressed as medians and ranges. The significance of differences between groups were determined with the Mann-Whitney U test.

\section{Results}

PERFORMANCE CHARACTERISTICS OF THE ASSAY

Using two control serum samples, the mean intraassay variation (expressed as coefficient of variation) was $7.6 \%$ (range $1.6-14.2$ ) and $6.6 \%$ (range $1 \cdot 8-12 \cdot 7)$ in seven consecutive assays. For the same seven assays these controls gave a mean (SD) of 83 $(4 \cdot 1)$ and $74 \cdot 1(4 \cdot 3)$ ELISA index units, giving interassay variations of 8.7 and 8.5 , respectively.

COMPARISON OF SERUM WITH BLOOD SPOT, SERUM SPOT, AND FINGER PRICK SPECIMENS

Paired serum and blood spot specimens were significantly related $(n=108, p<0 \cdot 001$ (fig 1$)$. There was a significant relationship between serum spot specimens and both serum and blood spot specimens, $\mathrm{p}<0.001$ and $\mathrm{p}<0.001$, respectively $(\mathrm{n}=87)$. The agreement between the different specimens was assessed by the determination of the mean difference (95\% confidence interval) for paired specimens. For blood spot specimens compared with serum specimens $(n=108)$ the mean difference was $2.7(1.6$ to 3.7) ELISA index units, and for the blood spot specimens compared with serum spot specimens $(n=87)$ the mean difference was $0.05(-0.9$ to 1.8$)$.

Finger prick sample results were closely related to those of paired blood spot and serum samples. Determination of agreement showed that the fingerprick blood spot specimens tended to give slightly lower results than paired blood spot and serum samples $(n=23)$, the mean difference being -1.6 


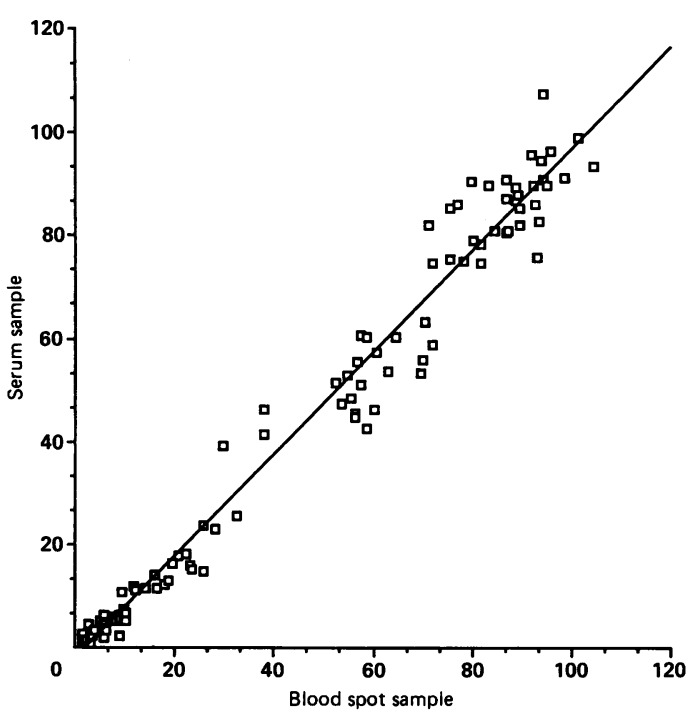

Fig 1 Relationship between paired blood spot samples and routine serum samples from venous blood. The plot is of 108 paired samples from normal subjects and bronchiectatic patients with and without cystic fibrosis. The least squares regression line is shown. The results are expressed as ELISA index units.

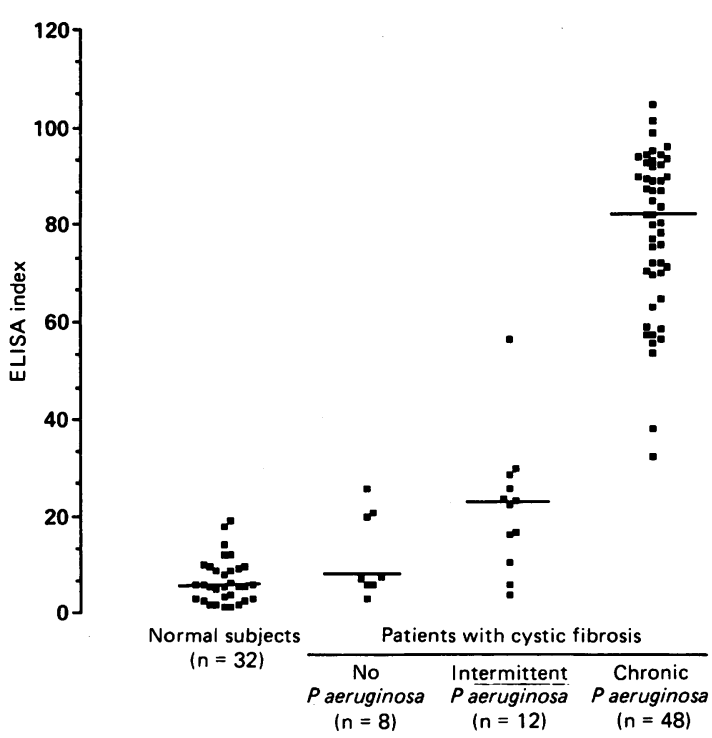

Fig 2 ELISA index results for normal subjects and patients with cystic fibrosis according to the isolation pattern for P aeruginosa. Blood spots were made from venous blood. Individual results are shown with the median for each group.
$(-4.0$ to 0.9$)$ and $-1.5(-3.6$ to 0.7$)$ ELISA index units, respectively.

\section{EFFECT OF BLOOD SPOT VOLUME}

This was assessed by making blood spots with 10,20 , 30 , and $50 \mu \mathrm{l}$ volumes of whole blood from a single patient; $10 \mu \mathrm{l}$ was the minimum volume from which a $6 \mathrm{~mm}$ disc could be reliably punched. There were no significant differences between discs, indicating that the blood volume had little effect on antibody determination (analysis of variance, $\mathrm{F}=1.232 ; 3$, $30 \mathrm{df}, \mathrm{p}=0 \cdot 315)$.

STORAGE OF BLOOD SPOT SPECIMENS

Paired blood spots were prepared from 28 patients. One sample was assayed freshly and a second blood spot specimen was stored at $-20^{\circ} \mathrm{C}$ for 21 to 28 days before eluates were prepared. An assessment of agreement revealed a mean difference of 1.5 ELISA index units with a $95 \%$ confidence interval of -1.7 to $4 \cdot 7$.

COMPARISON OF PATIENTS WITH CYSTIC FIBROSIS WITH AND WITHOUT $P$ AERUGINOSA INFECTION

There was no significant difference between patients with cystic fibrosis in whom $P$ aeruginosa had never been isolated from the sputum and healthy controls not known to have been infected at any time (fig 2). Patients with either intermittent isolation of $P$ aeruginosa (less than four isolates in one year) or chronic infection four or more isolations in one year) had significantly greater ELISA indices than controls $(p<0.0002)$. There was overlap, however, between the former group and both the control group and the group with cystic fibrosis who had never been infected.

\section{Discussion}

The collection of small volumes of blood on blotting paper is used in screening babies for phenylketonuria ${ }^{10}$ and neonatal hypothyroidism. ${ }^{11-13}$ The same simple procedure was successful for the measurement of antibodies of the IgG class in this study and gave absolute values close to those obtained with serum samples.

The blood spot system is dependent on a reliable and reproducible assay. Reported ELISAs for pseudomonas antibodies did not have the within and between assay performances of the highly developed method used here. Using the same antigen as in this study a similar ELISA gave intraplate, intra-assay, and interassay variations of $14 \%, 19 \%$, and $20 \%$, respectively. ${ }^{5}$ The assay reported here could be completed in one working day, whereas other reported assays require one or two overnight 
incubation periods. ${ }^{45}$ Blood spot samples could be stored at $-20^{\circ} \mathrm{C}$ for up to four weeks without deterioration, which suggests that such samples may be stored for long periods in such conditions. This is supported by the stability of such specimens after being stored for up to nine months at $-20^{\circ} \mathrm{C}$, which was as good as for paired serum specimens in storage. ${ }^{14}$ Another possibility yet to be studied is that blood spot specimens will keep for short periods, in a dry form at ambient temperatures, allowing them to be taken at home and posted to the laboratory for assay. This would be an advantage in epidemiological studies or for serial monitoring.

In the assay reported here normal subjects had low but detectable antibody titres, which probably indicates a general low degree of response in normal subjects. ${ }^{15}$ This group was not statistically different from patients with cystic fibrosis who had never grown $P$ aeruginosa from their sputum. The patients with cystic fibrosis and intermittent growth of $P$ aeruginosa were separated from normal controls but overlapped with both the non-infected patients with cystic fibrosis and those with chronic infection, which suggests a range of exposure and host response to $P$ aeruginosa. These findings confirm earlier reports and indicate the validity of the blood spot ELISA system reported here. ${ }^{516} 17$

It is not clear how to use data about antipseudomonal antibodies in the management of early infection. It is thought that intermittent isolation of $P$ aeruginosa occurs during a phase of harmless colonisation, and that treatment during this period may delay or halt progression to chronic infection. Vigorous antipseudomonal antibiotic treatment does protect the lungs against injury and prolongs survival in chronically infected subjects, ${ }^{18}$ but it is unknown if early intervention would have the same effect. The harmlessness of early colonisation is an assumption that could be tested by combining the method reported here with an index of lung destruction, such as measurement of urinary desmosine concentration. ${ }^{19}$ Such an approach would help to define the role of antibody measurements in cystic fibrosis and the value of intervention with antibiotics early in $P$ aeruginosa infection. In previous studies serial sampling has only been carried out in small numbers of patients at infrequent intervals, or simply to illustrate the value of an individual ELISA. ${ }^{516} 17$

Antibodies of the IgG class to $P$ aeruginosa can reliably be determined using finger prick samples of blood collected on to Guthrie cards. This method of collection had a high level of agreement with blood samples obtained by venepuncture, which allows the prospect of repeated sampling in babies and children with cystic fibrosis with minimum disturbance to the child or parent. Such studies may define the association of antipseudomonal antibodies and the acquisition of infection, and the value of their determination in the management of early $P$ aeruginosa infection in children with cystic fibrosis.

We acknowledge the support of Eli Lilly Ltd, and the Cystic Fibrosis Research Trust. VT was supported by a Commonwealth Medical Fellowship awarded by the Commonwealth Scholarship Commission. We thank Professor N Høiby of Copenhagen for the $P$ aeruginosa serotypes 01-17.

\section{References}

1 Pier GB. Pulmonary disease associated with Pseudomonas aeruginosa in cystic fibrosis: current status of the host-bacterium interaction. $J$ Infect Dis 1985;151:575-80.

2 Høiby N, Doring G, Schiotz PO. The role of immune complexes in the pathogenesis of bacterial infections. Annual Review of Microbiology 1986;40:29-53.

3 Dasgupta MK, Zuberbuhler P, Abbi A, et al. Combined evaluation of circulating immune complexes and antibodies to Pseudomonas aeruginosa as an immunologic profile in rclation to pulmonary function in cystic fibrosis. J Clin Immunol 1987;7:51-8.

4 Høiby N. Antibodies against Pseudomonas aeruginosa in sera from normal persons and from patients colonised with mucoid or non-mucoid Pseudomonas aeruginosa. Results obtained by means of crossed immunoelectrophoresis. Acta Pathologica ef Microbiologica Scandinavian Section C: Immunology 1977;85:O 142-8.

5 Brett MM, Ghoneim ATM, Littlewood JM, Losowsky MSç Development of enzyme linked immunosorbent assay (ELISA), to detect antibodies to Pseudomonas aeruginosa cell surface antigens in sera of patients with cystic fibrosis. J Clin Pathol 1986;39:1124-9.

6 Pedersen SS, Espersen F, Høiby N. Diagnosis of chronic pseudomonas aeruginosa infection in cystic fibrosis by enzyme linked immunosorbent assay. J Clin Microbiol 1987;25:1830-6.

${ }^{7}$ Høiby N. Pseudomonas aeruginosa infection in cystic fibrosis. Diagnostic and prognostic significance on Pseudomonas aeruginosa precipitins determined by means of crossed immunoelectrophoresis. A survey. Acta Pathologica et Microbiologica Scandinavica, section C Immunology 1977;262:(suppl):3-96.

$\checkmark$ Shale DJ, Faux JA. The evaluation of a quantitative enzymelinked immunosorbent assay (ELISA) for anti-A fumigatus IgG. J Immunol Methods 1985;77:197-205.

9 Bland JM, Altman DG. Statistical methods for assessing agreement between two methods of clinical measurement. Lancet 1986;i:307-10.

10 Guthric R, Susi A. A simple phenylalanine method for detecting phenylketonuria in large populations of newborn infants. Pediatrics $1963 ; 32: 338-43$.

11 Irie M. Enomoto K, Naruse H. Measurement of thyroidstimulating hormone in dried blood spot. Lancet 1975 ;ii: $1233-4$.

12 Dussault JH, Parlow A, Letarte J, Guyda H, Laberge C. TSH measurements from blood spots on filter paper: a confirmatory screening test for neonatal hypothyroidism. J Pediatr 1976;89: 550-2.

13 Larsen PR. Merker A, Parlow AF. Immunoassay of human TSH using dried blood samples. Journal of Clinical Endocrinology 1976:42:987-90.

14 Guimaraes MCS, Castilho EA, Celeste BJ, Nakahara OS, Netto VM. Longterm storage of IgG and IgM on filter papers for use in parasitic disease seroepidemiology surveys. Bull Pan Am Health Organ 1985;19:16-28. 
${ }^{15}$ Cost KM, West KS, Brinsen D, Polk HC. Measurement of human antibody activity against Escherichia coli and Pscudomonas aeruginosa using formal entreated whole organisms in an ELISA technique. J Immunoassay 1985;6:23-43.

16 Brett MM, Ghoneim ATM, Littlewood JM. Serum antibodies to Pseudomonas aeruginosa in cystic fibrosis. Arch Dis Child 1986;61:1114-20.

${ }^{17}$ Brett MM, Ghoneim ATM, Littlewood JM. Serum IgG antibodies in patients with cystic fibrosis with early Pseudomonas aeruginosa infection. Arch Dis Child 1987;62:357-61.

${ }^{18}$ Pedersen SS, Jensen T, Høiby N, Koch C, Flensborg EW. Management of Pseudomonas aeruginosa lung infection in
Danish cystic fibrosis patients. Acta Paediatr Scand 1987;76: 955-61.

${ }^{19}$ Bruce MC, Poncz L, Klinger JD, Stern RC, Tomashefski JF, Dearborn DG. Biochemical and pathological evidence for proteolytic destruction of lung connective tissue in cystic fibrosis. Am Rev Respir Dis 1985;132:529-35.

Correspondence to Dr DJ Shale, Respiratory Medicine Unit, University of Nottingham, City Hospital, Hucknall Road, Nottingham NG5 1PB.

Accepted 9 June 1989 